\title{
PENGARUH PENGETAHUAN KEWIRAUSAHAAN, PRAKTIK KERJA INDUSTRI DAN MOTIVASI BERPRESTASI TERHADAP MINAT BERWIRAUSAHA SISWA KELAS XII KOMPETENSI KEAHLIAN PEMASARAN SMK NEGERI BISNIS DAN MANAJEMEN KOTA PADANG
}

\author{
Meri Rahmania \\ Dosen Program Studi Pendidikan Ekonomi STKIP- PGRI Sumbar \\ Jl. Gunung Pangilun No.1, Padang Sumatera Barat \\ Email : nadia.zahrani@yahoo.com
}

Submitted: 2015.12.08 Reviewed: 2016.06.24 Accepted: 2016.06.24

http://dx.doi.org/10.22202/economica.2015.v4.i1.331

\begin{abstract}
This research aims to analyze (1) influence of knowledge entrepreneurship, industrial work practice and motivation of entrepreneurship interest against an accomplished students of class XII marketing skills competency SMK Negeri Padang city business and management. (2) the influence of knowledge entrepreneurship entrepreneurship interest to grade XII Foreign marketing skills competency SMK Padang city business and management. (3) the influence of the working practices of the industry of interest entrepreneurship grade XII Foreign marketing skills competency SMK Padang city business and management.(4) the influence of motivation overachievers against interest entrepreneurship marketing students of SMK Negeri Padang city business and management. the number of samples as much as 102 people. Analysis techniques using descriptive analysis and inductive analysis: test the assumptions of classical and multiple regression analysis. Results of research knowledge entrepreneurship, industrial work practices and motivational impact of entrepreneurship interest achievers grade XII Foreign marketing skills competency SMK Padang city business and management

Abstrak

Penelitian ini bertujuan untuk menganalisis (1) pengaruh pengetahuan kewirausahaan, praktek kerja industry dan motivasi berprestasi terhadap minat berwirausaha siswa kelas XII kompetensi keahlian pemasaran SMK Negeri Bisnis dan Manajemen Kota Padang. (2) pengaruh pengetahuan kewirausahaan terhadap minat berwirausaha siswa kelas XII kompetensi keahlian pemasaran SMK Negeri Bisnis dan Manajemen Kota Padang. (3) pengaruh praktek kerja industri terhadap minat berwirausaha siswa kelas XII kompetensi keahlian pemasaran SMK Negeri Bisnis dan Manajemen Kota Padang. (4) pengaruh motivasi berprestasi terhadap minat berwirausah siswa pemasaran SMK Negeri Bisnis dan Manajemen Kota Padang dengan jumlah sampel sebanyak 102 orang. Teknik analisis data dengan menggunakan analisis deskriptif dan analisis induktif: uji asumsi klasik dan analisis regresi berganda. Hasil penelitian: pengetahuan kewirausahaan, praktek kerja industry dan motivasi berprestasi berpengaruh terhadap minat berwirausaha siswa kelas XII kompetensi keahlian pemasaran SMK Negeri Bisnis dan Manajemen Kota Padang.
\end{abstract}

Keywords: entrepreneurship, knowledge work practices, the motivation industry achievers and interest of entrepreneurship 


\section{PENDAHULUAN}

Sekolah menengah kejuruan (SMK) adalah salah satu bentuk satuan pendidikan formal yang menyelenggarakan pendidikan kejuruan pada jenjang pendidikan menengah sebagai lanjutan dari SMP/MTs atau bentuk lain yang sederajat atau lanjutan dari hasil belajar yang diakui sama/setara SMP/MTs, (www.wikipedia.org). Dalam Standar kompetensi lulusan pada satuan pendidikan menengah kejuruan bertujuan untuk meningkatkan kecerdasan, pengetahuan, kepribadian, ahklak mulia, serta keterampilan untuk hidup mandiri dan mengikuti pendidikan lebih lanjut sesuai dengan kejuruannya. (www.dikti.go.id)

Saat ini persaingan dalam dunia kerja sangatlah ketat, penyerapan tenaga kerja dalam dunia usaha dan industri serta perekrutan pegawai negeri sangatlah terbatas dan dengan tingkat kompetensi yang tinggi. Melihat kondisi tersebut di atas, maka dunia pendidikan harus mampu berperan aktif menyiapkan sumber daya manusia terdidik yang mampu menghadapi berbagai tantangan kehidupan lokal, nasional, regional maupun internasional yang tidak hanya menguasai teori tapi juga mampu menerapkan dalam kehidupan sosial dan yang kreatif yang mampu menciptakan lapangan pekerjaan untuk dirinya sendiri dan orang lain atau seorang wirausaha.

Minat berwirausaha di Indonesia masihlah sangat rendah. Dibandingkan negara tetangga, Indonesia masih tertinggal jauh hanya sekitar $0,18 \%$ dari total 238 juta penduduk Indonesia. Jumlah wirausahawan Malaysia mencapai 4\%, Thailand 4,1\%, dan Singapura 7,2\%. Agar bisa menggerakkan ekonomi nasional, jumlah wirausahawan minimal $2 \%$ (http://www.jpnn.com). Sementara itu Data Kementerian Pendidikan dan Kebudayaan, minat berwirausaha para lulusan lembaga pendidikan untuk lulusan SMA/SMK sederajat masih rendah, hanya sebesar $22,63 \%$ dari 17,41 juta sisanya ingin mencari pekerjaan.

(www.menkokesra.go.id).

Melihat kondisi dari masih rendahnya minat berwirausaha siswa SMK dan tingginya tingkat pengangguran siswa SMK mengharuskan siswa SMK untuk memiliki minat yang tinggi terhadap pembukaan unit usaha yang baru (berwirausaha) dari pada mencari pekerjaan setelah menamatkan pendidikan.Minat merupakan faktor pendorong yang menjadikan seseorang lebih giat bekerja dan memanfaatkan setiap peluang yang ada dengan mengoptimalkan potensi yang tersedia. Hal ini sejalan dengan pendapat Walgito(2003:148), minat tidak muncul begitu saja tetapi tumbuh dan berkembang sesuai dengan faktor-faktor yang mempengaruhinya.

" Minat berwirausaha dipengaruhi oleh beberapa faktor diantaranya karakteristik kepribadian, faktor demografi dan karakteristik lingkungan. Karakteristik kepribadian seperti efikasi diri dan kebutuhan akan prestasi merupakan faktor yang signifikan memunculkan minat berwirausaha, faktor demografi seperti umur, jenis kelamin, latar belakang pendidikan dan pengalaman bekerja seseorang diperhitungkan sebagai penentu bagi minat berwirausaha, faktor lingkungan seperti hubungan sosial, infrastruktur fisik dan institusional serta faktor budaya dapat mempengaruhi minat berwirausaha" (Indarti, 2008:121).

Sekolah sebagai lingkungan terdekat siswa setelah lingkungan tempat tinggal, diharapkan mampu memberikan pengaruh yang besar dalam menumbuhkan minat berwirausaha para siswa.Pembekalan pengetahuan kewirausahaan kepada siswa-siswa SMK di sekolah sangat perlu dilakukan. Semakin banyak pengetahuan kewirausahaan siswa SMK, akan semakin terbuka wawasannya tentang kewirausahaan. Banyak hasil penelitian menyimpulkan bahwa pengetahuan kewirausahaan berpengaruh terhadap 
adanya minat berwirausaha. Pengetahuan kewirausahaan dapat diperoleh siswa dari pendidikan di sekolah dengan adanya mata pelajaran kewirausahaan.

Proses pelatihan kerja di dunia usaha bertujuan untuk membekali siswa menguasai kompetensi keahlian produktif terstandar, menginternalisasi sikap, nilai dan budaya dunia usaha yang berorientasi pada standar mutu, nilai-nilai ekonomi, kritis, produktif dan kompetitif serta sikap kewirausahaan, sehingga setelah siswa menyelesaikan prakteknya akan muncul keinginan atau minat dari para siswa untuk dapat membuka usaha atau berwirausaha seperti usaha ditempat mereka melakukan kegiatan prakteknya.

Rendahnya minat berwirausaha siswa sangat dipengaruhi oleh rendahnya motivasi berprestasi siswa SMK.Banyak penelitian yang mengungkapkan bahwa rendahnya minat berwirausaha faktor terbesarnya karena rendahnya motivasi berprestasi dari siswa tersebut.Dorongan untuk selalu berprestasi tinggi harus ada dalam diri seorang yang ingin menjadi wirausaha yang sukses, karena dengan adanya motivasi berprestasi yang tinggi dapat membentuk mental yang ada pada diri mereka untuk selalu lebih unggul dan mengerjakan segala sesuatu melebihi standar yang ada. Indikator siswa memiliki motivasi berprestasi yang tinggi dalam kehidupan sehari-hari, hal ini dapat tercermin pada ketekunan siswa untuk belajar untuk mencapai nilai yang tertinggi

Fenomena rendahnya minat berwirausaha siswa SMK juga dapat dilihat dari data yang diperoleh dari Guru Bimbingan Konseling yang mendata rencana siswa setelah lulus SMK, dimana diperoleh data rendahnya minat berwirausaha dikalangan siswa kelas XII semua jurusan SMK Bisnis dan Manajemen Kota Padang, karena lebih dari 50\% siswa di SMK N 2 dan SMK N 3 Padang memilih rencana untuk melanjutkan kuliah, $40 \%$ mencari pekerjaan dan kurang dari $1 \%$ yang mempunyai rencana untuk membuka usaha sendiri atau berwirausaha.

Berdasarkan uraian permasalahan di atas di mana masih rendahnya minat berwirausaha siswa SMK dikarenakan berbagai faktor diantaranya minimnya pengetahuan kewirausahaan siswa, praktek kerja industri masih belum memberikan pengalaman dan pengetahuan yang benarbenar bermanfaat bagi siswa setelah mereka mereka menyelesaikan praktek tersebut yang mampu menumbuhkan minat berwirausaha, serta masih rendahnya motivasi berprestasi siswa SMK, penulis tertarik untuk melakukan penelitian tentang pengaruh ketiganya dalam membentuk minat berwirausaha siswa, dengan judul : "Pengaruh Pengetahuan Kewirausahaan dan Praktik Kerja Industri dan Motivasi Berprestasi Terhadap Minat Berwirausaha Siswa Kelas XII Kompetensi Pemasaran SMK Negeri Bisnis dan Manajemen Kota Padang".

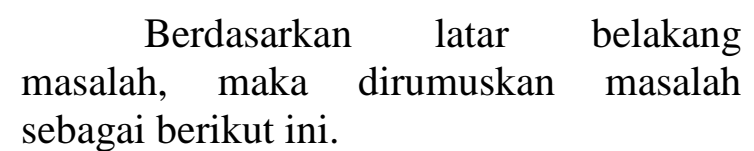

a. Apakah pengetahuan kewirausahaan, pengalaman praktek kerja industri dan motivasi berprestasi berpengaruh secara signifikan terhadap minat wirausaha siswa kompetensi keahlian pemasaran SMK Negeri Bisnis dan Manajemen Kota Padang?

b. Sejauh mana pengaruh pengetahuan kewirausahaan berpengaruh terhadap minat berwirausaha siswa komptensi keahlian pemasaran SMK Negeri Bisnis dan Manajemen Kota Padang?

c. Sejauh mana pengaruh pengalaman praktik kerja indutri terhadap minat berwirausaha siswa kompetensi keahlian pemasaran SMK Negeri Bisnis dan Manajemen Kota Padang.

d. Sejauh mana pengaruh motifasi berprestasi terhadap minat berwirausaha siswa kompetensi keahlian pemasaran SMK Negeri Bisnis dan Manajemen Kota Padang. 
Santoso(1993:19) menyatakan bahwa minat wirausaha adalah gejala psikis untuk memusatkan perhatian dan berbuat sesuatu terhadap wirausaha itu dengan perasaan senang, karena membawa manfaat bagi dirinya maupun orang lain. Jadi dapat dikatakan bahwa minat berwirausaha adalah keinginan, ketertarikan, serta kesediaan individu melalui ide-ide yang dimiliki untuk bekerja keras atau berkemauan keras untuk berusaha memenuhi kebutuhan hidupnya, tanpa merasa takut dengan resiko yang akan terjadi, dapat menerima tantangan, percaya diri, kreatif, dan inovatif serta mempunyai kemampuan dan keterampilan untuk memenuhi kebutuhan.

Minat berwirausaha muncul disebabkan oleh berbagai faktor.Menurut para ahli faktor munculnya minat berwirausaha berasal dari faktor internal atau faktor dari dalam diri sendiri dan faktor ekternal atau faktor dari luar diri. Faktor Pendidikan Kewirausahaan merupakan salah satu faktor ekternal yang mempengaruhi munculnya minat berwirausaha, hal ini telah dinyatakan oleh Zimmerer (1996:12)

Salah satu Faktor internal yang mempengaruhi minat berwirausaha seseorang adalah adanya motivasi berprestasi, seperti yang diungkapkan Suryana (2011:30),

McClelland dalam Suryana (2011:47) menekankan pentingnya kebutuhan berprestasi, karena orang yang berhasil dalam bisnis dan industri adalah orang yang berhasil menyelesaikan segala sesuatu. Ia menandai tiga motivasi utama , yaitu : 1) Pengabungan. 2) Kekuatan. 3) Prestasi.

Menurut Gede Anggan Suhandana dalam Suryana (2011:52) Motivasi berprestasi adalah suatu nilai social yang menekankan pada hasrat untuk mencapai hasil terbaik guna mencapai kepuasan pribadi. Sementara itu Suryana (2011:53) : "Bahwa kebutuhan berprestasi wirausaha (n'Ach) terlihat dalam bentuk tindakan untuk melakukan sesuatu yang lebih baik dan efisien dibanding sebelumnya. Wirausaha yang memiliki motif berprestasi tinggi pada umumnya memiliki ciri-ciri sebagai berikut:

1. Ingin mengatasi sendiri kesulitan dan pesoalan-persoalan yang timbul pada dirinya.

2. Selalu memerlukan umpan balik yang segera untuk melihat keberhasilan dana kegagalan.

3. Memiliki tanggung jawab personal yang tinggi.

4. Berani menghadapi resiko dengan penuh perhitungan.

5. Menyukai dan melihat tantangan secara seimbang.

Praktik kerja industri atau sering disebut prakerin atau magang menurut Anwar (2004:50) yaitu:

"Bentuk penyelenggaraan pendidikan keahlian professional yang memadukan secara sitematik dan sinkron program pendidikan di sekolah dan program penguasaan keahlian yang diperoleh melalui kegiatan bekerja langsung di dunia kerja, terarah untuk mencapai suatu tingkat keahlian profesional tertentu."

Penelitian ini terdiri atas empat variabel yaitu Pengetahuan Kewirausahaan, Praktik Kerja Industri, Motivasi Berprestasi dan Minat Berwirausaha yang dapat digambarkan dalam model kerangka pemikiran sebagai berikut:

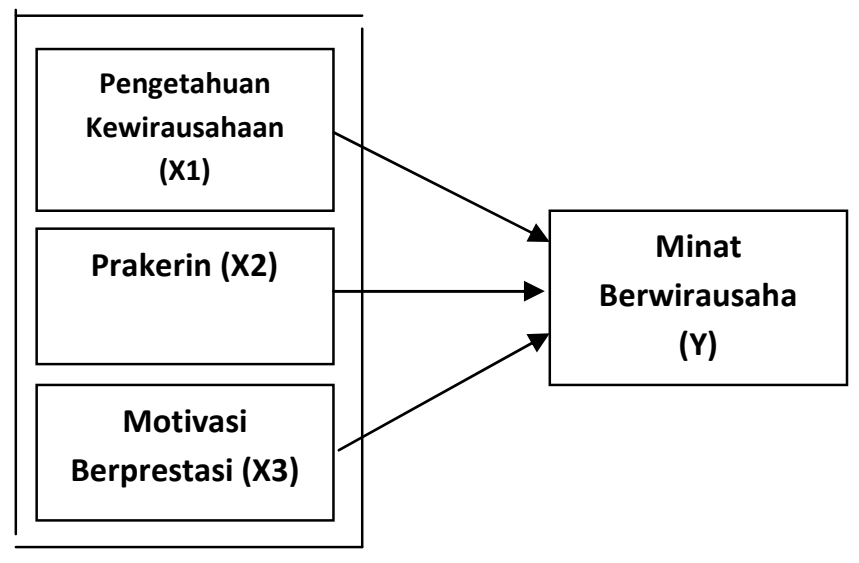


Berdasarkan pada rumusan masalah yang diteliti dan kerangak konseptual penelitian, maka hipotesis utama penelitian ini adalah.

1. Pengetahuan kewirausahaan, praktik kerja industri dan motivasi berprestasi berpengaruh secara signifikan terhadap minat berwirausaha siswa kompetensi keahlian pemasaran kelas XII SMK Negeri Bisnis dan Manajemen Kota Padang.

2. Pengetahuan kewirausahaan berpengaruh signifikan terhadap minat berwirausaha siswa kompetensi keahlian pemasaran kelas XII SMK Negeri Bisnis dan Manajemen Kota Padang

3. Pengalaman praktik kerja Industri berpengaruh signifikan terhadap minat berwirausaha siswa kompetensi keahlian pemasaran kelas XII SMK Negeri Bisnis dan Manajemen Kota Padang.

4. Motivasi berprestasi berpengaruh signifikan terhadap minat berwirausaha siswa kompetensi keahlian pemasaran kelas XII SMK Negeri Bisnis dan Manajemen di Kota Padang.

\section{METODE PENELITIAN}

Penelitian ini dapat digolongkan ke dalam penelitian deskriptif dan asosiatif karena menerangkan suatu gejala dan peristiwa dari kejadian yang telah, terjadi, serta menentukan ada tidaknya pengaruh suatu varabel terhadap variable lainnya.

Penelitian diselenggarakan di SMK Negeri Bisnis dan Manajemen yang ada diKota Padang, yaitu SMK Negeri 2 dan SMK Negeri 3 Padang, penelitian dilakukan pada bulan Januari 2014

Populasi dalam penelitian ini adalah seluruh siswa kelas XII kompetensi keahlian pemasaran yang telah menyelesaikan Praktek Kerja Industri (Prakerin), dengan jumlah populasi 137 siswa.Sampel sebanyak 102 siswa yang ditentukan dengan teknik proportional random sampling

\section{PEMBAHASAN}

Minat Berwirausaha dengan menggunakan data angket yang terdiri dari 20 item pernyataan yang diberikan kepada siswa Minat Berwirausaha.skor rata variabel Minat Berwirausaha siswa di SMK Negeri Bisnis Dan Manajemen Kota Padang adalah 3,98 dengan Tingkat Capaian Responden (TCR) sebesar 79,61. Hal ini menunjukkan bahwa variabel Minar Berwirausaha masuk kedalam kategori cukup.menciptakan lapangan pekerjaan sendiri.

Instrumen Kewirausahaan (X1) disusun sebanyak 25 pertanyaan dalam bentuk pilihan berganda. Tiap butir soal yang betul jawabanya mendapat skor bobot 4 dan jawaban yang salah diberi skor bobot 0 , jadi jika siswa dapat menjawab 25 pertanyaan akan mendapat tertinggi 100, dan yang terendah mendapat nilai 0 . Jenis dan Prosedur penyusunan rangking berdasarkan Mean dan Deviasi Standar, mengunakan jenis Penyusunan Urutan Kedudukan atas Lima Rangking.

Berdasarkan hasil pengolahan hasil tes pilihan berganda Pengetahuan Kewirausahaan yang dilakukan, diperoleh nilai Mean $=76,6667$ dan Nilai SD ( Standart Deviasi ) $=7,804$, sehingga diperoleh hasil sebagai berikut :

\section{Sekali \\ $\mathrm{M}+1,5 \mathrm{SD}=76,66667+(1,5)(7,804)=$ $\mathbf{8 8 , 3 7 2 6 7}$}

$\mathrm{M}+0,5 \mathrm{SD}=76,66667+(0,5)(7,804)=$ 80,56867

M - 0,5 SD = 7,66667 - (0,5) $(7,804)=$ 72,76467

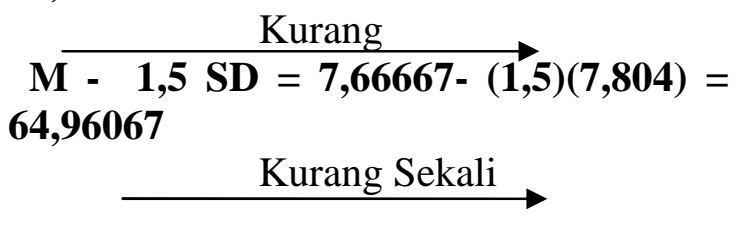


Dari pengolahan diperoleh informasi bahwa hasil pengskoran untuk variabel pengetahuan kewirausahaan terbagi atas lima kelompok, yaitu pada interval 89 keatas atau rangking 1 sebanyak 4 siswa $(3,92 \%), 81-88$ atau rangking 2 sebanyak 21 siswa $(20,58 \%)$, 73-80 atau rangking 3 sebanyak 41 siswa $(40,19 \%), 65-72$ atau rangking 4 sebanyak 27 (26,47\%.) dan 64 kebawah atau rangking 5 sebanyak 9 orang siswa $(8,82 \%)$. Dari data diatas dapat diambil kesimpulan bahwa siswa jurusan pemasaran SMK Negeri Bisnis dan Manajemen Kota Padang mempunyai Pengetahuan Kewirausahaan yang cukup, dimana 40,19\% atau 41 orang siswa mempunyai nilai dengan interval 73-80. Hal ini menunjukan bahwa masih diperlukan berbagai upaya untuk meningkatkan Pengetahuan Kewirausahaan siswa jurusan pemasaran SMK Negeri Bisnis dan Manajemen Kota Padang, agar minat berwirausaha siswa juga meningkat.

Pada variabel praktek kerja industri (prakerin) indikator yang digunakan adalah pelaksanaan praktek kerja industri dan hasil dari praktek kerja industri. Dari hasil pengolahan data diperoleh informasi bahwa skor rata - rata variabel praktek kerja industri siswa jurusan pemasaran SMK Negeri Bisnis Dan Manajemen Kota Padang adalah sebesar 4,25 dengan tingkat capaian responden $84,90 \%$. Hal ini menunjukkan bahwa variabel masuk kedalam kategori sangat baik. Artinya menurut siswa, pelaksanaan praktek kerja industri sudah sangat baik, namun begitu masih perlu dilakukan peningkatan oleh pihak sekolah agar pelaksanaan praktek kerja industri di SMK Negeri Bisnis Dan Manajemen Kota Padang berjalan dengan lebih baik lagi sehingga dapat meningkat minat berwirausaha bagi siswa.

Pada variabel Motivasi berprestasi indikator yang digunakan adalah yaitu: 1) Mandiri, 2) Memiliki Tanggung Jawab yang Tinggi, 3) Berani menghadapi resiko dengan penuh tantangan, 4) Menyukai dan melihat tantangan secara seimbang, 5) Memiliki Rasa percaya diri. Dari hasil pengolahan data diperoleh informasi bahwa rata - rata variabel motivasi berprestasi siswa jurusan pemasaran SMK Negeri Bisnis Dan Manajemen Kota Padang adalah sebesar 3,83 dengan tingkat capaian responden $76,67 \%$. Hal ini menunjukkan bahwa varibel motivasi berprestasi siswa berada pada kategori cukup. Artinya motivasi berprestasi siswa masih perlu ditingkatkan

\section{Uji Persyaratan Analisis}

Pengujian normalitas data dilakukan dengan menggunakan metode Kolmogorov-Smirnov (uji-KS). Adapun hasil uji normalitas untuk variabel pengetahuan kewirausahaan (X1) diperoleh sig Probality 0,095, Praktik kerja industry (X2) nilai sig probality 0,253, variabel motivasi berprestasi (X3) nilai sig 0,776 , dan variabel minat berwirausaha (Y) nilai sig 0,159. Masing-masing variabel memiliki niali sig lebih besar dari nilai alpha 0,05 , dengan demikian dapat disimpulkan bahwa semua variabel penelitian telah berdistribusi secara normal.

Berdasarkan analisis dengan program SPSS 16 diperoleh hasil uji homogenitas variabel (X1) 0,07, (X2) 0,18 dan (X3)0,26, dimana masing - masing variabel memiliki nilai sig > alpha 0,05. Sehingga dapat dikatakan ketiga variabel adalah homogen.

Uji multikolinearitas dengan melihat nilai VIF (varian inflation factor) pada model regresi. Berdasarkan hasil pengolahan data variabel pengetahuan kewirausahaan (X1) nilai VIF adalah 1,085, variabel praktik kerja industri (X2) nilai VI adalah 1,071 dan variabel motivasi berprestasi (X3) nilai VIF adalah 1,081. Seluruh variabel memiliki nilai $\mathrm{VIF}<5$, jadi dapat dikatakan tidak terdapat masalah multikolinieritas.

Hasil pengujian Regresi Berganda untuk X1, X2, X3 dan Y dengan program SPSS 16 diperoleh hasil sebagai berikut : 
Tabel .Hasil Analisi Regresi Ganda X1,X2,dan X3 terhadap Y

Coefficients $^{\mathrm{a}}$

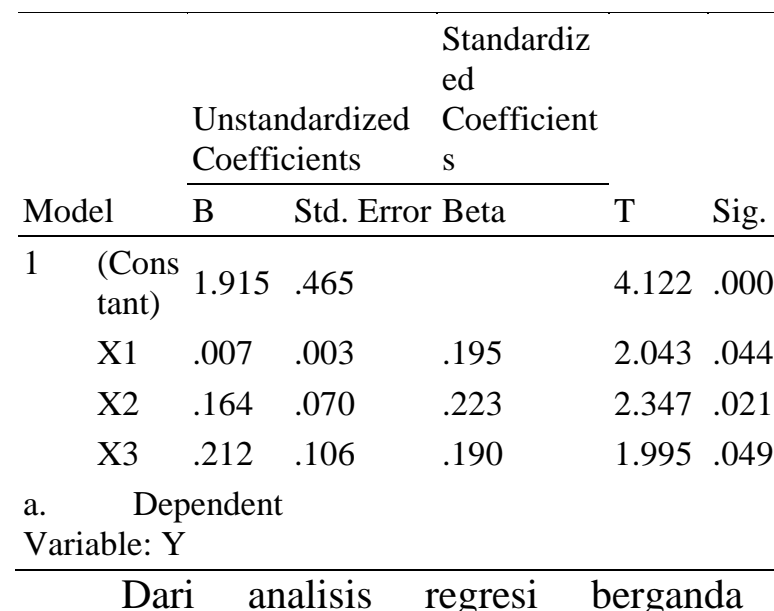

diperoleh Adjusted $\mathrm{R}$ square adalah 0,150 artinya konstribusi variabel pengetahuan kewirausahaan, praktik kerja industri dan motivasi berprestasi terhadap minat berwirausaha adalah $15 \%$ sedangkan sisanya yaitu $85 \%$ dipengaruhi oleh factor lain. Adapun dari tabel maka dapat diperoleh persamaan regresi yaitu :

$Y=1.915+0,07 X 1+0,164 X 2+0,212 X 3$

Dimana :

Y : Minat Berwirausaha

$\mathrm{X} 1$ : Pengetahuan Kewirausahaan

$\mathrm{X} 2$ : Praktik Kerja Industri

X3 : Motivasi Berprestasi

Berdasarkan persamaan tersebut diketahui nilai konstanta sebesar 1.915, menunjukan bahwa tanpa adanya pengetahuan kewirausahaan, praktik kerja industry dan motivasi berprestasi, minat berwirausaha siswa tersebut mencapai 1,915 .

Pengaruh Pengetahuan Kewirausahaan, Prakerin dan Motivasi Berprestasi Terhadap Minat Berwirausaha

Dari hasil pengolahan data diperoleh nilai $F_{\text {hitung }}$ sebesar 6,950 dengan nilai signinifikansi 0,000. Sedangkan nilai $F_{\text {tabel }}$ pada tingkat kepercayaan $95 \%(\alpha=0,05)$ maka nilai $F_{\text {tabel }} \quad 2,70$. Dengan demikian $F_{\text {hitung }}>F_{\text {tabel }}$, yaitu $6,950>$
2,70, oleh karena itu Ho ditolak dan Ha diterima, yang berarti bahwa Pengetahuan Kewirausahaan, Pratik Kerja Industri dan Motivasi Berprestasi secara serempak atau bersama-sama berpengaruh terhadap Minat Berwirausaha siswa kompetenssi keahlian pemasaran SMK Negeri Bisnis dan Manajemen Kota Padang. Hal ini juga dapat dilihat dari nilai signifikansi pada Uji $F$ yaitu 0,000 yang lebih kecil dari $\alpha=$ 0,05 , artinya secara bersama-sama variabel Pengetahuan Kewirausahaan, Praktik Kerja Industri dan Motivasi Berprestasi berpengaruh signifikan terhadap Minat Berwirausaha.

Dari analisis regresi ganda juga didapatkan konstribusi ketiga variabel bebas melalui Adjusted $R$ Square sebesar 0,150. Dengan demikian dapat disimpulkan bahwa pengetahuan kewirausahaan, praktik kerja industry dan motivasi berprestasi secara bersama-sama memiliki pengaruh sebesar $15 \%$ terhadap minat berwirausaha siswa kompetensi keahlian pemasaran SMK Negeri Bisnis dan Manajemen Kota Padang. Sedangkan $85 \%$ dipengaruhi oleh variabel-variabel lain yang tidak diteliti dalam penelitian ini.

\section{Pengetahuan Kewirausahaan terhadap Minat Berwirausaha.}

Berdasarkan hasil Uji parsial pdiperoleh $t_{\text {hitung }}$ setiap variabel bebas. Nilai $t_{\text {hitung }}$ akan dibandingkan dengan $t_{\text {tabel }}$ pada tingkat kepercayaan $95 \%$ $(\alpha=0,05)$. Nilai $t_{\text {tabel }}: 1,980$, sementara itu pengaruh parsial variabel Pengetahuan Kewirausahaan (X1) diperoleh nilai $t_{\text {hitung sebesar 2,043 dengan }}$ demikian $t_{\text {hitung }}>t_{\text {tabel }}$, yaitu $2,043>$ 1,980 dan dengan sig. $0,044<0,05$, maka Ho ditolak dan Ha diterima, yang artinya bahwa variabel Pengetahuan Kewirausahaan berpengaruh signifikan terhadap Minat Berwirausaha siswa kelas XII kompetensi keahlian pemasaran SMK Negeri Bisnis dan Management Kota Padang. Sementara itu besar koefisien regresi pengetahuan kewirausahaan sebesar $0,07 \quad(7 \%)$ artinya setiap 
peningkatan pengetahuan kewirausahaan $1 \%$ akan meningkatkan minat berwirausaha siswa sebesar $7 \%$

\section{Praktik Kerja Industri terhadap Minat Berwirausaha.}

Berdasarkan hasil Uji parsial pada table diatas diperoleh $t_{\text {hitung }}$ setiap Ivariabel bebas. Nilai $t_{\text {hitung }}$ akan dibandingkan dengan $t_{\text {tabel }}$ pada tingkat kepercayaan $95 \%(\alpha=0,05)$. Nilai $t_{\text {tabel }}$ : 1,980, sementara itu pengaruh parsial variabel Praktik Kerja Industri (X2) diperoleh nilai $t_{\text {hitung }}$ sebesar 2,347 dengan demikian $t_{\text {hitung }}>t_{\text {tabel }}$, yaitu $2,347>1,980$ dan dengan sig. 0,021< 0,05, maka Ho ditolak dan Ha diterima, yang artinya bahwa variabel Praktik Kerja Industri berpengaruh signifikan terhadap Minat Berwirausaha siswa kelas XII jurusan pemasaran SMK Negeri Bisnis dan Management Kota Padang. Adapun besar koefisien regresi variabel praktik kerja industry sebesar $0,164 \quad(16,4 \%)$, yang artinya setiap peningkatan pengalaman praktik kerja industry sebesar $1 \%$ akan meningkatkan minat berwirausaha siswa sebesar $16,4 \%$.

\section{Motivasi Berprestasi terhadap Minat Berwirausaha}

Berdasarkan hasil Uji parsial pada table 21 diperoleh $t_{\text {hitung }}$ setiap variabel bebas. Nilai $t_{\text {hitung }}$ akan dibandingkan dengan $t_{\text {tabel }}$ pada tingkat kepercayaan $95 \% \quad(\alpha=0,05)$. Nilai $t_{\text {tabel }}: 1,980$, sementara itu pengaruh parsial variabe] Motivasi Berprestasi (X3) diperoleh nilai $t_{\text {hitung }}$ sebesar 1,995 dengan demikian $t_{\text {hitung }}>t_{\text {tabel }}$, yaitu $1,995>1,980$ dan dengan sig. $0,049<0,05$, maka Ho ditolak dan $\mathrm{Ha}$ diterima, yang artinya bahwa variabel Motivasi Berprestasi berpengaruh signifikan terhadap Minat Berwirausaha siswa kelas XII kompetensi keahlian pemasaran SMK Negeri Bisnis dan Management Kota Padang. Besar koefisien regresi variabel motivasi berprestasi sebesar 0,212 (21,2\%), artinya setiap peningkatan motivasi berprestasi sebesar $1 \%$ akan meningkatkan minat berwirausaha siswa sebesar $21,2 \%$.

\section{PEMBAHASAN}

\section{Pengaruh Pengetahuan Kewirausahaan terhadap Minat Berwirausaha}

Pengetahuan kewirausahaan merupakan salah satu aspek penting dalam berwirausaha karena dengan adanya pengetahuan yang memadai atau cukup, maka akan semakin terbuka wawasan siswa tentang kewirausahaan sehingga mampu menumbuhkan minat seseorang untuk berwirausaha dan juga akan mampu mengelola dengan baik.

Hal ini didukung oleh teori Zimmerer (1996:12) yang mengatakan bahwa salah satu factor pendorong tumbuhnya minat kewirausahaan seseorang adalah dengan adanya pendidikan kewirausahaan yang dalam arti bahwa pengetahuan kewirausahaan yang diperoleh melalui pendidikan kewirausahaan baik itu diperoleh dari pendidikan formal ataupun non formal mempengaruhi munculnya atau tumbuhnya minat berwirausaha. Begitu juga pendapat Hendro (2011) menyatakan bahwa pengetahuan kewirausahaan yang luas tidak hanya akan meningkatkan minat berwirausaha saja, melainkan juga menghasilkan yang lebih besar dari pada mencari kerja/menjadi karyawan.

Dengan demikian pembekalan pengetahuan kewirausahaan disekolah perlu ditingkatkan. Pengetahuan yang diberikan tidak hanya bersifat parsial atau siswa hanya memahami sebagian dari wirausaha, tapi siswa harus memahami seluruh karakteristik dalam dunia usaha, ketika siswa telah memiliki pengetahuan kewirausahaan yang luas, tentu akan semakin menumbuhkan minat siswa untuk berwirausaha, dan hendaknya pengetahuan kewirausahaan siswa ditindak lanjuti dengan praktek kewirausahaan. Agar siswa tidak hanya memiliki pengetahuan tetapi juga memiliki ketrampilan yang 
mendukung

pengetahuan tersebut.Sehingga minat siswa untuk berwirausaha semakin mantap.

\section{Pengaruh Praktek Kerja Industri Terhadap Minat Berwirausaha}

Praktek kerja industri (prakerin) diadakan dengan tujuan untuk memberikan pengalaman langsung kepada siswa bagaimana dunia usaha dan dunia kerja yang sebenarnya, setelah siswa dibekali dengan pembelajaran disekolah, di dunia usaha atau dunia industri siswa dapat mengaplikasikan pembelajaran yang telah mereka pelajari terutama pembelajaran kewirausahaan, sehingga menambah pengetahuan siswa tentang bagaimana dunia wirausaha itu sesungguhnya sehingga mampu menumbuhkan minat siswa untuk berwirausaha. SMK Negeri Bisnis dan Manajemen Kota Padang telah melaksanakan progaram praktek kerja industri kepada siswa-siswi mereka, baik itu jurusan pemasaran maupun jurusan yang lainnya yang ada pada setiap sekolah.

Dengan demikian menujukan bahwa pelatihan adalah proses pembelajaran terhadap seseorang untuk meningkatkan kemampuan atau prilaku (pengetahuan, skill dan sikap) untuk mencapai tujuantujuan tertentu yang diinginkan. Selain itu menunjukan proses praktik kerja industry didunia usaha bertujuan membekali siswa menguasai kompetensi keahlian produktif terstandar, menginternalisasi sikap, nilai dan budaya dunia usaha yang berorientasi pada standar mutu, nilai-nilai ekonomi, kritis, produktif dan kompetitif serta mampu menumbuhkan minat berwirausaha.

Temuan penelitian ini diperkuat oleh Chalpin (2006: 179) Dengan Pengalaman maka diperoleh pengetahuan dan keterampilan dari praktik atau dari luar usaha belajar, keterampilan yang dikuasai seseorang sebagai akibat dari perbuatan atau pekerjaan yang telah dilakukan sebelumnya selama jangka waktu tertentu. Seseorang dikatakan memiliki keterampilan apabila telah memiliki tingkat penguasaan pengetahuan dan pengalaman yang relevan dan memadai sesuai dengan bidang keahliannya.

Jadi, dengan adanya praktek kerja industri yang baik, yang bisa memberikan pengalaman dan pengetahuan tentang dunia wirausausaha yang sesungguhnya maka siswa akan mendapatkan pengalaman dan pengetahuan yang baik pula dari kegiatan yang telah dilakukan siswa pada saat pelaksanaan praktek kerja industri, sehingga minat berwirauasahanya akan semakin meningkat.

\section{Pengaruh Motivasi Berprestasi Terhadap Minat Berwirausaha}

Dorongan untuk selalu berprestasi tinggi harus ada dalam diri seseorang, karena akan dapat membentuk mental yang ada pada diri mereka untuk selalu lebih unggul mengerjakan sesuatu melebihi standar yang ada. Para ahli mengatakan bawa seseorang yang memiliki minat berwirausaha dikarenakan adanya motif, yaitu motif berprestasi.

Untuk itu perlu ada upaya untuk dapat meningkatkan motivasi berprestasi siswa agar dapat menumbuhkan minat siswa untuk berwirausaha, terutama untuk indicator menyukai dan melihat tantangan secara seimbang dimana ketercapaian TCRnya paling rendah diantara indicator yang lain. Ini menujuka bahwa siswa tidak terlalu menyukai hal-hal yang penuh tantangan, ketakutan akan resiko yang akan terjadi dan sifat yang lebih suka mencari situasi aman membuat siswa tidak tertantang untuk mencoba hal-hal baru terutama untuk berwirausaha karena dibayangi dengan resiko kegagalan dan ketidak amanan.

\section{Pengaruh Pengetahuan Kewirausahaan, Praktik Kerja Industri dan Motivasi Berprestasi terhadap Minat Berwirausaha}

Sebelum memasuki dunia wirausaha, munculnya minat berwirausaha dari 
seseorang merupakan langkah awal yang sangat bisa menuntun orang tersebut untuk dapat merealisasikan minat yang ada dalam dirinya dalam bentuk tindakan nyata yaitu memulai berwirausaha.

Minat berwirausahan yang ada dalam diri seorang bisa tumbuh karena berbagai macam faktor yang mempengaruhinya.Bisa dari faktor internal (dari dalam diri sendiri) atau faktor dari eksternal (dari luar diri). Pengetahuan Kewirausahaan yang diperoleh melalui proses pembelajaran di sekolah memberikan dan membuka wawasan para siswa mengenai dunia wirausaha secara teoritis, dengan bekal pengetahuan yang dimiliki membuat siswa menjadi tertarik atau berminat untuk berwirausaha.

Kegiatan praktik kerja industri merupakan proses pembelajaran yang dilakukan diluar lingkungan sekolah. Prakerin memberikan pengetahuan dan pengalaman langsung kepada siswa bagaimana dunia usaha dan dunia industri sesungguhnya. Pengalaman yang diperoleh siswa selama prakerin menjadi pemicu munculnya minat berwirausaha bagi para siswa, karena siswa dapat melihat secara langsung usaha-usaha yang mampu sukses atau berhasil sehingga akan muncul keinginan dari para siswa untuk bisa seperti itu juga.

Motivasi berprestasi merupakan dorongan yang kuat dari diri seseorang untuk berprestasi. Orang yang mempunyai motivasi berprestasi akan lebih gigih dan percaya diri, bersunguh-sunguh untuk mencapai apa yang diinginkannya. Menyukai tantangan dan berani mengambil resiko serta mandiri.hal ini diperlukan menumbuhkan minat berwirausaha bagi para siswa dikarenakan untuk berwirausaha memerlukan orangorang yang mempunyai dorongan yang kuat dari dirinya sendiri bukan karena keterpaksaan, berani mengambil resiko dikarenakan berwirausaha dipenuhi dengan resiko yang tidak semua orang mau dan mampu untuk mengambil resiko tersebut.
Jadi, pengetahuan kewirausahaan, praktik kerja industri dan motivasi berprestasi secara bersama-sama atau simultan mempengaruhi muncul atau tumbuhnya minat berwirausaha.

\section{PENUTUP}

Pengaruh secara simultan antara variabel Pengetahuan Kewirausahaan (X1), Praktik Kerja Industri (X2) dan Motivasi Berprestasi (X3) terhadap Minat Berwirausaha (Y) sebesar $15 \%$ ( NilaiAdjusted $R$ Square 0,15 ), walaupun tidak terlalu besar tapi cukup memberikan konstribusi trhadap muncul/tumbuhnya minat berwirausaha dari para siswa.

Dari hasil pengolahan data dan pembahasan yang dilakukan, penelitian ini menghasilkan kesimpulan sebagai berikut:

1. Pengetahuan Kewirausahaan memiliki pengaruh signifikan terhadap Minat Berwirausaha siswa kompetensi keahlian pemasaran SMK Negeri Bisnis dan Manajemen Di Kota Padang. Dengan semakin bertambahnya atau meningkatnya pengetahuan siswa terhadap wirausaha, akan dapat meningkatkan juga minat dari siswa untuk berwirausaha

2. Praktek kerja industri memiliki pengaruh signifikan terhadap Minat Berwirausaha siswa kompetensi keahlian pemasaran SMK Negeri Bisnis dan Manajemen Kota Padang. Pengalaman yang didapat dari pelaksanaan praktek kerja industri, mampu meningkatkan minat berwirausaha dari para siswa.

3. Motivasi Berprestasi berpengaruh signifikan terhadap minat berwirauasah siswa kompetensi keahlian pemasaran SMK Negeri Bisnis dan Manajemen Kota Padang. Keinginan yang besar atau dorongan yang kuat untuk selalu berprestasi merupakan suatu hal yang harus ada pada diri seorang wirausaha, karena dapat membentuk mental yang ada pada diri seorang untuk selalu bisa lebih unggul dan mengerjakan sesuatu melebihi standar yang ada. Sehingga 
apa bila seorang siswa mempunyai motivasi berprestasi yang tinggi mereka akan lebih mandiri tidak bergantung kepada orang lain sehinggan akan memunculkan atau menumbuhkan minat berwirausaha bagi siswa sebagai bentuk kemandirian mereka.

4. Pengetahuan Kewirausahaan, Praktek kerja industri dan Motivasi Berprestasi memiliki pengaruh signifikan terhadap minat berwirausaha siswa jurusan pemasaran SMK Negeri Bisnis dan Manajemen Kota Padang. Apabila siswa sudah dibekali dengan pengetahuan kewirausahaan, pelaksanaan praktek kerja industri sudah dilakukan dengan baik, dan Motivasi Berprestasi sudah meningkat akan dapat meningkatkan Minat Berwirausaha siswa jurusan pemasaran SMK Negeri Bisnis dan Manajemen Kota Padang.

\section{Berdasarkan kesimpulan diatas, maka untuk meningkatkan minat berwirausaha siswa jurusan pemasaran SMK Negeri Bisnis dan Manajemen Kota Padang, maka dapat disarankan kepada :}

1. Kepala Sekolah.

a. Meningkatkan kompetensi guru kewirausahaan dengan memberikan kesempatan seluas-luasnya kepada guru kewirausahaan untuk mengikuti diklat/pelatihan tentang kewirausahaan.

b. Membuat peraturan yang memuat nilai-nilai kewirausahaan dan mengikat kepada seluruh warga sekolah dan siapa saja yang ada di lingkungan sekolah. Peraturan tersebut meliputi : tata tertib siswa, kode etik guru dan karyawan, serta peraturan lain yang mengatur terhadap siapa saja yang pada saat itu berada di lingkungan sekolah.

c. Membuat program yang mampu membuka wawasan kewirausahaan siswa, ini dapat dilakukan melalui kegiatan seperti: ceramah, diskusi, mengundang lulusan SMK yang berhasil, mengundang wirausahawan yang berada di sekitar sekolah agar menceritakan keberhasilan dan kegagalan yang pernah mereka alami atau mengunjungi perusahaan, melalui pengamatan langsung melalui pemagangan atau studi banding.

d. Meningkatkan fasilitas/sarana prasarana untuk praktek kewirausahaan disekolah.

e. Memperluas kerjasama dengan Dunia Usaha yang bagus dan sesuai dengan kompetensi keahlian siswa sehingga benar-benar mampu memberikan pengetahuan dan pengalaman yang bermanfaat bagi siswa selama mengikuti kegiatan prakerin

f. Mewajibkan kepada guru secara bergilir untuk mengikuti kegiatan magang didunia usaha atau industri, agar guru juga bisa mendapatkan pengalaman secara langsung tentang dunia usaha dan industri guna peningkatan kompetensi dan wawasan bagi guru itu sendiri.

2. Guru.

a. Melibatkan diri secara lansung dalam kegiatan-kegiatan untuk peningkatan pengetahuan kewirausahaan, seperti mengikuti seminar-seminar kewirausahaan, diklat atau pelatihan kewirausahaan.

b. Lebih variatif dalam metode mengajar kewirausahaan, agar siswa bisa lebih tertarik untuk mempelajari kewirausahaan.

c. Mengikutsertakan siswa dalam kegiatan Unit Produksi dan melaksanakan kegiatan ekstrakurikuler kewirausahaan. Dengan melibatkan siswa dalam unit produksi, diharapkan penanaman konsep, penanaman sikap, pemahaman teknis serta pembekalan pengalaman awal berwirausaha dapat dilakukan. 
Sedangkan dengan kegiatan ekstrakurikuler, maka diharapkan dapat menanamkan sikap, pemberian pembekalan teknis dan memberikan pengalaman berwirausaha.

d. Memberikan contoh kepada para siswa tentang penerapan nilai-nilai kewirausahaan pada saat berada dilingkungan sekolah ataupun dilingkungan luar sekolah.

3. Pihak Dunia Usaha dan Industri,

a. Membimbing, mengarahkan, membuka wawasan, menanamkan sikap dan memberikan bekal teknis berwirausaha kepada para siswa selama kegiatan prakerin berlangsung.

\section{DAFTAR PUSTAKA}

10.22202/economica.2015.v4.i1.331

Alma, Buchari. 2011.Kewirausahaan : Bandung: Alfabeta.

Hendro.2011.Dasar-dasar Kewirausahaan panduan untuk mahasiswa mengenal dan memahami dan memasuki dunia bisnis, Gelora Aksara Pratama.

Indarti, Nurul \& Rostiani, Rokhima. 2008. Kewirausahaan Mahasiswa Mengenal : Studi Kewirausahaan pada MAhasiswa Universitas Brawijaya

Santoso.1993. Kompetisi dan Kepercayaan Diri Remaja. Yogyakarta: Liberty

Saiman,L.2009.Kewirausahaan

Teori,Praktik dan Kasus-kasus.Jakarta: Salemba EmpatSlameto. 2010. Belajar dan Faktor-Faktor yang Mempengaruhi. Jakarta:Rineka Cipta.

Sukadji, Soetarlinah \& Evita E. SinggihSalim (2001). Sukses di Perguruan Tinggi (Edisi Khusus). Depok: Psikologi Pendidikan Fakultas Psikologi Universitas Indonesia

Suryana.2011. Kewirausahaan,Pedoman Praktis Kiat dan Proses Menuju Sukses.Bandung : Alfabeta.
Soemanto, Wasty, 1992.Pendidikan Wirausaha(Sekuncup Ide Profesional).Malang:Bina Aksara,.

Walgito,Bimo. 2003.Pengantar Psikologi Umum.Yogyakarta : Andi Offset

Zimmerer,W.Thomas, Norman M.Scarborough

Entrepreneurship The New Venture Formation. New Jersey : Prentice Hall International Inc.

\section{Artikel}

Indonesia Butuh 4,6 Juta Wirausahawan. www.jpnn.com. Diakses 10 Desember 2013.

Minat Berwiraswasta Orang Indonesia Masih Rendah(www. menkokesra.go.id), diakses 10 Desember 2013

Pengertian SMK (www.wikipedia.org).

Standar Kompetensi Lulusan pada Satuan PendidikanSMK(www.dikti.go.id/files / atur/KTSP-SMK / 02.) 